\title{
Biological parameters for germination of selected summer weed species: first step to transfer the hydrothermal model AlertInf to Croatia
}

\author{
Valentina Šoštarčić ${ }^{1}$, Roberta Masin $^{2}$, Donato Loddo ${ }^{3}$, Ema Brijačak ${ }^{1}$, Maja Šćepanović ${ }^{1}$
}

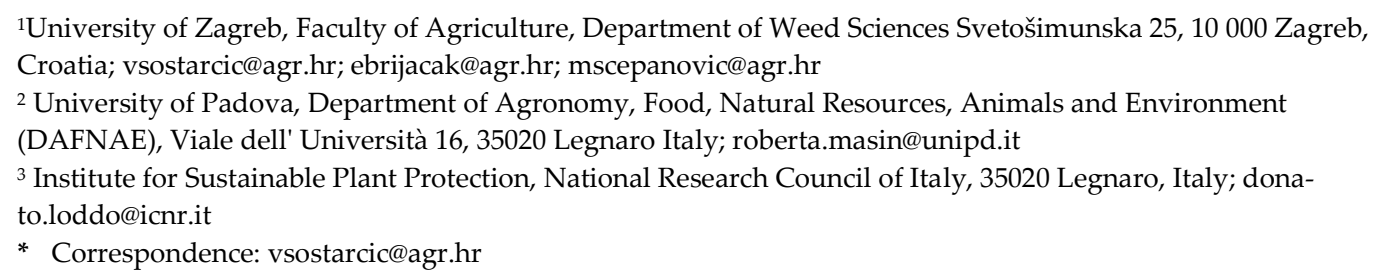

\begin{abstract}
The efficacy of weed management depends on the correct control timing according to the seedling emergence dynamics. Since soil temperature and soil moisture are two main factors that determine weed germination, the hydrothermal time model can be used to predict their emergence. The aim of this study was to estimate the base temperature $\left(\mathrm{T}_{\mathrm{b}}\right)$ and base water potential $\left(\Psi_{\mathrm{b}}\right)$ for germination of Chenopodium album, Amaranthus retroflexus, Setaria pumila and Panicum capillare collected from fields in continental Croatia and then to compare these values with those of Italian populations embedded in the AlertInf model. Germination tests were performed at seven constant temperatures (ranging from 4 to $27^{\circ} \mathrm{C}$ ) and eight water potentials (0.00 to - $\left.1.00 \mathrm{MPa}\right)$. Estimated $\mathrm{T}_{\mathrm{b}}$ and $\Psi_{\mathrm{b}}$ were $3.4^{\circ} \mathrm{C},-1.38 \mathrm{MPa}$ for $\mathrm{C}$. album, $13.9^{\circ} \mathrm{C},-0.36 \mathrm{MPa}$ for A. retroflexus, $6.6^{\circ} \mathrm{C}$, $-0.71 \mathrm{MPa}$ for S. pumila and $11.0^{\circ} \mathrm{C},-0.87 \mathrm{MPa}$ for P. capillare, respectively. According to the criterion of overlap of the $95 \%$ confidence intervals, only $\mathrm{T}_{\mathrm{b}}$ of $\mathrm{C}$. album, and $\Psi_{\mathrm{b}}$ of A. retroflexus were similar between Croatian and Italian populations. Further field experiments should be conducted in the Croatian field to monitor weed emergence patterns of C. album and to calibrate the AlerInf equation parameters.
\end{abstract}

Keywords: base temperature; base water potential; maize; predictive weed emergence model; weed germination

\section{Introduction}

Integrated Weed Management recommends the use of post-emergence herbicides when it is possible to select an effective herbicide or combination of herbicides based on the weed flora composition. Although such an application can be tailored to the specific botanical composition of the real weed flora, efficient control is highly dependent on timing according to weed emergence dynamics [1]. Therefore, knowledge of the timing and duration of weed emergence could help to achieve effective herbicide application without subsequent corrective treatments [2]. In addition, compared to standard management practice, it allows for lower herbicide application and lower weed control costs [3]. Weed emergence data are a basis for the development of predictive weed emergence models. These models provide the percentage of cumulative weed emergence achieved daily in the field, with the aim of suggesting the best time for farmers to control weeds [1]. Several predictive weed emergence models have been developed and are currently available for growers of maize [4,5], soybeans [6,2] and winter cereals $[7,8]$ in Europe and the United States. These models are often based on the concept of thermal time (TT) or hydrothermal time (HTT) [9], depending on whether they consider only temperature (TT) or temperature and soil moisture (HTT) as triggers for germination. HTT models 
start calculating hydrothermal units when the soil temperature and water potential reach the value of the estimated base temperature $\left(\mathrm{T}_{\mathrm{b}}\right)$ and base water potential $\left(\Psi_{\mathrm{b}}\right)$ for germination of certain weed species. The prediction of HTT models is usually more accurate, as they are able to predict the pauses in seedling emergence caused by low soil water potential $[1,3,10]$, which could not be predicted by TT models. The calculation of HT requires the estimation of biological parameters, which are base temperature $\left(\mathrm{T}_{\mathrm{b}}\right)$ and base water potential $\left(\Psi_{b}\right)$ for germination, to simulate the seedlings emergence according to weather trends [11].

In Croatia, maize is the most important annual crop, averaging 260,000 hectares per year, which corresponds to about 32\% of the country's arable land [12]. Maize is almost always cultivated without irrigation and weed control relies mainly on post-emergence herbicides. Prediction of weed emergence is therefore very important to identify the correct timing for herbicide application. Currently, there are no developed models, therefore, the transfer of the existing model from geographically close areas $(4,11]$ would be of great benefit to maize growers.

The criteria for the transfer of a HTT model developed in another area are the presence of the main weed species in the existing model and the overlap of the values of the biological parameters of the domestic and foreign populations built into the model. In case of overlapping values, the existing model can be validated in maize field without repeated monitoring of weed emergence dynamics lasting many years.

The inter-population variability of weed species may limit the transferability of the HTT model, as it has been reported that local populations may develop different germination behavior as an adaptation to local environmental conditions [11, 13]. For example, differences between $\mathrm{T}_{\mathrm{b}}$ values in Italian and Portuguese populations of Datura stramonium L. [13], American and European populations of A. artemisiifolia L. [14] and German and French populations of Chenopodium album L. and Echinochloa crus-galli (L.) P. Beauv [15] have been reported. In contrast, similar $\mathrm{T}_{\mathrm{b}}$ values were found for Amaranthus retroflexus L., Abutilon theophrasti Med. and Chenopodium album L. between populations from different regions of Italy, Veneto and Tuscany [1]. Thus, to transfer a model to geographical areas other than that of creation, the behavior of the local population should be tested [11].

Of the HTT models developed so far, the geographically closest to the continental part of Croatia is the AlertInf model, developed in Italy (Veneto) for predicting the emergence of ten weed species: A. theophrasti, Digitaria sanguinalis (L.) Scop., E. crus-galli, Polygonum persicaria L., Setaria pumila (L.) P. Beauv, Setaria viridis (L.) Beauv., Solanum nigrum L., A. retroflexus, C. album, and Sorghum halepense (L.) Pers. $[1,4]$.

Previous studies found no statistical difference between the biological parameters adopted for the Italian population of A. theophrasti included in the AlertInf model and the values estimated using the same methodology for a Croatian population [16]. The results of these preliminary studies indicate the possibility of transferring AlertInf to Croatia, but further studies are needed to include other thermophilic weed species that are common in maize fields in Croatia. Hence, the aim of this research was to estimate $\mathrm{Tb}$ and $\Psi_{\mathrm{b}}$ for four weed species A. retroflexus, C.album, S. pumila and Panicum capillare L. collected from fields in continental Croatia, and then to compare these values with the values of the Italian populations embedded in the AlertInf model.

\section{Materials and Methods}

\subsection{Site Description and Comparison}

In order to verify the transferability of the AlertInf model from Italy to Croatia, the values of biological parameters of seeds collected from Croatia (Zagreb) and Italy (Padova) were compared. According to Köppen-Geiger climate classification [17], Zagreb is classified as Dfb as cold climate, precipitation without dry season and warm summer. Padova is classified as Cfa as temperate climate, precipitation without dry season and warm summer. For location Padova average annual temperatures and precipitation were 
taken from Masin et al. [6] and for location Zagreb from Croatian Meteorological and Hydrological Service. Average annual precipitation in Zagreb is $861.1 \mathrm{~mm}$ with minimum precipitation in February $(44.6 \mathrm{~mm})$ and maximum in September $(101.6 \mathrm{~mm})$. Average annual temperature is $11.8^{\circ} \mathrm{C}$, with minimum temperature in January $\left(-3.2^{\circ} \mathrm{C}\right)$ and maximum in August $\left(25.0^{\circ} \mathrm{C}\right)$. Padova has an average annual precipitation about $850 \mathrm{~mm}$ uniformly distributed throughout the year. Average annual temperature is $12.2^{\circ} \mathrm{C}$, with temperature increases from January (average minimum value: $-1.5^{\circ} \mathrm{C}$ ) to July (average maximum value: $27.2^{\circ} \mathrm{C}$ )

\subsection{Seed material}

The seeds of S. pumila, P. capillare, A. retroflexus and C. album were hand-picked from plants in maize fields at physiological maturity. The seeds of C. album and S. pumila were collected at the Experimental Station of the University of Zagreb Faculty of

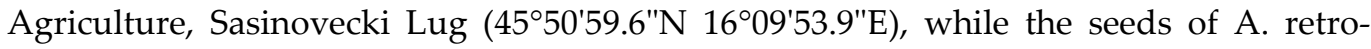
flexus were collected at the Experimental Station Maksimir $\left(45^{\circ} 49^{\prime} 34.3^{\prime \prime} \mathrm{N} 16^{\circ} 01^{\prime} 49.8^{\prime \prime} \mathrm{E}\right)$ and P. capillare were collected at the site Lipovec Lonjski ( $\left.45^{\circ} 44^{\prime} 51.9^{\prime \prime N} ; 16^{\circ} 23^{\prime} 12.4^{\prime \prime E}\right)$. The collected seeds were brought to the laboratory, cleaned, sieved and stored in paper bags in the refrigerator $\left(4^{\circ} \mathrm{C}\right)$ until the beginning of the experiment.

\subsection{Germination experiments}

Experiments to estimate base temperature and base water potential for germination were conducted at University of Padova, Department of Agronomy, Food, Natural resources, Animals and Environment and University of Zagreb, Faculty of Agriculture, Department of Weed Science from 2013 to 2020. Prior to the start of the experiments, a preliminary germination test in the climate chamber (W87R, KW Apparecchi Scientifici SRL, Italy) at constant temperature $\left(25^{\circ} \mathrm{C}\right)$ and photoperiod $12 \mathrm{~h}: 12 \mathrm{~h}$ (day: night) was conducted to check the germination capacity of the seeds. Seed populations that achieved a germination higher than $60 \%$ were included in further studies.

The estimation of the base temperature of four weed species was performed by testing the germination at six or seven constant temperatures with photoperiod $12 \mathrm{~h}: 12 \mathrm{~h}$ (day: night) simultaneously in the different climatic chambers. To prevent the growth of pathogens on the seeds and on filter paper, seeds were sterilized with $1 \%$ hydrogen peroxide and washed with distilled water. Three replicates of 100 seeds or five replicates of 50 seeds were placed in the Petri dish on Whatman ${ }^{\circledR}$ filter paper covered with $5 \mathrm{ml}$ distilled water and sealed with parafilm. The initial temperature was defined for each weed species as one degree lower than the base temperature previously established from the literature [11, 18 - 20]. Therefore, C. album and S. pumila were tested to a constant temperature of $4,8,12,16,20,24,28^{\circ} \mathrm{C}$. Furthermore, the germination of A. retroflexus was tested at $9,12,15,18,21,24,27^{\circ} \mathrm{C}$ and P. capillare at $6,9,12,15,18,21,24,27$ and $30^{\circ} \mathrm{C}$.

To estimate base water potential of each species, germination test was carried out exposing seeds to different level of water potential, that is different level of water availability. Three replicates per 100 seeds or five replicates per 50 seeds were placed at eight different water potential solutions. For this purpose, polyethylene glycol (PEG) 6000 (Sigma-Aldrich Chemie GmbH 25322-68-3) was used to prepare solutions with eight water stress levels: 0.00 (pure distilled water), $-0.05,-0.10,-0.25,-0.38,-0.50,-0.80,-1.00$ MPa according to Michel and Kaufmann [21]. The seeds were placed in transparent plastic containers $10 \mathrm{~cm}$ in diameter and $7 \mathrm{~cm}$ high, as described by Masin et al. [1]. Containers with $50 \mathrm{ml}$ prepared solution were placed at a constant temperature of $22^{\circ} \mathrm{C}$ and a photoperiod of $12 \mathrm{~h}: 12 \mathrm{~h}$ (day: night).

In both germination experiments, seeds were defined as germinated when the seed radicle was $1 \mathrm{~mm}$ long. Germinated seeds were counted and removed twice daily for seeds incubated at temperatures above $20^{\circ} \mathrm{C}$ and all water potentials above $-0.38 \mathrm{MPa}$ and once daily for seeds temperatures below $20^{\circ} \mathrm{C}$ and water potential below $-0.38 \mathrm{MPa}$. The germination test was considered complete when no germination was detected for 10 
consecutive days. Germination test lasted from 9 to 95 days depending on the temperature or water potential and tested weed species.

The temperature in the climate chambers was recorded hourly with temperature data loggers (HOBO UA-001-08, Onset Computer Corporation, Bourne, MA). Temperature deviations $\pm 0.5^{\circ} \mathrm{C}$ were considered acceptable.

\subsection{Statistical Analysis and Statistical Methods}

Mean percentage of germination was calculated for each treatment. The germination dynamics curve was generated using the logistic function in the Bioassay97 statistical program [22] to determine initial ( $\left.t_{10}\right)$, medium $\left(t_{50}\right)$ and final $\left(t_{90}\right)$ germination time using the formula:

$C G=100 / 1+\exp \{a[\ln (t+0.0000001)-\ln (b)]\}$

Where $C G$ is the percentage of cumulative germination, $t$ time expressed in days, $a$ is the slope of the curve and $b$ is the inflection point. The initial $\left(t_{10}\right)$, medium $\left(t_{50}\right)$ and final (t90) germination time i.e., the time it takes 10, 50 and $90 \%$ of the germinating seeds to germinate, are determined by the slope of curve (b). The effect of temperature and water potential on germination percentages and germination dynamics $\left(t_{10}, t_{50}\right.$ and $\left.t_{90}\right)$ was analyzed by means of variance analysis (ANOVA). After the significant F-test, the LSD test for $\mathrm{P}=0.05$ was used to compare the mean values.

The biological germination parameters were determined using germination dynamics data at different temperatures and water potentials for each species studied. The reciprocal of $t_{50}\left(1 / t_{50}\right)$ was used to establish the linear regression line against the incubation temperature or water potential [1]. The values of $\mathrm{T}_{\mathrm{b}}$ and $\Psi_{\mathrm{b}}$ were presented as the point where the linear regression line intersects the abscissa. The 95\% confidence intervals for $\mathrm{T}_{\mathrm{b}}$ and $\Psi_{\mathrm{b}}$ were determined using the bootstrap method [23]. The values obtained for the biological parameters of the Croatian populations were compared with the values of Italian built into the AlertInf model, according to the criterion of overlap of the $95 \%$ confidence intervals [1]. If there is no overlapping of the confidence intervals between the two populations, a significant difference is determined. 


\section{Results}

3.1. Weeds germination at different temperatures and water potentials 2).

Analysis of variance showed significant influence $(\mathrm{P}<0.0001)$ of studied temperatures and water potential to weed germination $($ Table 1 and

Table 1. Final germination (\%) of C. album, S. pumila, A. retroflexus and P. capillare at studied temperatures.

\begin{tabular}{|c|c|c|c|c|c|c|c|c|c|c|c|c|c|c|}
\hline 7 & \multicolumn{14}{|c|}{ Final germination (\%) } \\
\hline${ }^{\circ} \mathrm{C}$ & 4 & 6 & 8 & 9 & 12 & 15 & 16 & 18 & 20 & 21 & 24 & 27 & 28 & 30 \\
\hline G album & $10.3 \mathrm{~d}$ & - & $36.3 \mathrm{c}$ & - & $41 \mathrm{c}$ & - & $97 \mathrm{a}$ & - & $96.3 \mathrm{a}$ & - & $98 \mathrm{a}$ & - & $60.3 \mathrm{~b}$ & - \\
\hline Stpumila & $0 \mathrm{~d}$ & - & $60.4 \mathrm{c}$ & - & $79.6 \mathrm{~b}$ & - & $89.6 \mathrm{ab}$ & - & $90 \mathrm{ab}$ & - & $93.2 \mathrm{a}$ & - & - & - \\
\hline A.1retroflexus & - & - & $0 \mathrm{e}$ & - & $0.67 \mathrm{e}$ & $9.33 \mathrm{~d}$ & - & $77.67 \mathrm{c}$ & - & $87.67 \mathrm{~b}$ & $94.67 \mathrm{a}$ & $99 \mathrm{a}$ & - & - \\
\hline P.2capillare & & $0 \mathrm{e}$ & - & $0 \mathrm{e}$ & $6.5 \mathrm{e}$ & $61.8 \mathrm{c}$ & - & $93.8 \mathrm{a}$ & - & $82.2 \mathrm{~b}$ & $93.5 \mathrm{a}$ & $36.2 \mathrm{~d}$ & - & $36.0 \mathrm{~d}$ \\
\hline
\end{tabular}

Means within a row followed by the same letter are not significantly different $(\mathrm{P}>0.05)$ according to the LSD test. 
The germination of the species studied varied between 0.67 and $99 \%$ depending on incubation temperature or weed species. Among the weed species tested, C. album showed the ability to germinate at the lowest temperature $\left(4^{\circ} \mathrm{C}\right)$, while other species started to germinate at $8^{\circ} \mathrm{C}$ (S. pumila) or $12^{\circ} \mathrm{C}$ (A. retroflexus and P. capillare). The highest germination percentage of all four species was reached at $24^{\circ} \mathrm{C}$ : C. album (98\%), A. retroflexus $(95 \%)$, S. pumila $(93 \%)$ and P. capillare $(93 \%)$. However, A. retroflexus achieved similar germination percentage also at $27^{\circ} \mathrm{C}$, or $\mathrm{C}$. album and S. pumila at temperature range $16-24^{\circ} \mathrm{C}$. Germination began to decrease as the temperature dropped, but this process was species-specific. Germination of C. album and S. pumila decreased at temperatures $\leq 8^{\circ} \mathrm{C}$. Germination percentage of $\mathrm{P}$. capillare decreased at temperatures $\leq 15^{\circ} \mathrm{C}$ and then plunged at $12^{\circ} \mathrm{C}$, while A. retroflexus showed a sharp reduction of germination even at $15^{\circ} \mathrm{C}$. These results indicate that incubation temperatures affect greatly the germination of tested weed species.

Similarly, water potential greatly affected the germination of weed species. For all tested weed species germination began to decrease as the water potential dropped (Table 2). Germination of S. pumila and C. album showed a reduction from water potential of -0.50 and $-0.38 \mathrm{MPa}$, respectively. A. retroflexus presented a first decrease of germination at $-0.10 \mathrm{MPa}$ and then a strong inhibition from -0.25 MPa. P. capillare ceased germination at $-1.00 \mathrm{MPa}$. All weed species presented almost no germinated seeds at -0.80 and -1.00 MPa. Taking together, germination of all species decreased significantly at lower water potentials, but the ability for germination at different water potential was also species specific.

Table 2. Final germination of studied weed species at different water potentials (MPa).

\begin{tabular}{lcccccccc}
\hline \multirow{2}{*}{ Species } & \multicolumn{7}{c}{ Water potential (MPa) } \\
& $\mathbf{0 . 0 0}$ & $\mathbf{- 0 . 0 5}$ & $\mathbf{- 0 . 1 0}$ & $\mathbf{- 0 . 2 5}$ & $\mathbf{- 0 . 3 8}$ & $\mathbf{- 0 . 5 0}$ & $\mathbf{- 0 . 8 0}$ & $\mathbf{- 1 . 0 0}$ \\
\hline A. retroflexus & $78.3 \mathrm{ab}$ & $84.7 \mathrm{a}$ & $72.7 \mathrm{~b}$ & $11.7 \mathrm{c}$ & $3.3 \mathrm{~cd}$ & $1.7 \mathrm{~d}$ & $0.7 \mathrm{~d}$ & $0.0 \mathrm{~d}$ \\
P. capillare & $69.8 \mathrm{ab}$ & $75.5 \mathrm{a}$ & $57.2 \mathrm{~b}$ & $32.8 \mathrm{c}$ & $13.8 \mathrm{de}$ & $19.2 \mathrm{~d}$ & $0.5 \mathrm{e}$ & $0.0 \mathrm{e}$ \\
C. album & $66.3 \mathrm{a}$ & $67.0 \mathrm{a}$ & $67.7 \mathrm{a}$ & $63.0 \mathrm{a}$ & $20.7 \mathrm{~b}$ & $7.3 \mathrm{c}$ & $2.3 \mathrm{c}$ & $0.0 \mathrm{c}$ \\
S. pumila & $88.4 \mathrm{a}$ & $80.4 \mathrm{ab}$ & $63.6 \mathrm{bc}$ & $62.8 \mathrm{bc}$ & $60.0 \mathrm{c}$ & $23.0 \mathrm{~d}$ & $1.2 \mathrm{e}$ & $0.0 \mathrm{e}$ \\
\hline
\end{tabular}
end of germination to $24.38 \mathrm{~d}$. 
Table 3. Germination dynamic ( $\left.\mathrm{t}_{10}, \mathrm{t}_{50}, \mathrm{t} \mathrm{t}_{0}\right)$ at the different studied temperatures.

\begin{tabular}{|c|c|c|c|c|c|c|c|c|c|c|c|c|}
\hline \multirow{2}{*}{${ }^{\circ} \mathrm{C}$} & \multicolumn{3}{|c|}{ P. capillare } & \multicolumn{3}{|c|}{ C. album } & \multicolumn{3}{|c|}{ S. pumila } & \multicolumn{3}{|c|}{ A. retroflexus } \\
\hline & $\mathbf{t}_{10}$ & $\mathbf{t}_{50}$ & $\mathbf{t}_{90}$ & $\mathbf{t}_{10}$ & $\mathbf{t}_{50}$ & $\mathbf{t}_{90}$ & $\mathbf{t}_{10}$ & $\mathbf{t}_{50}$ & $\mathbf{t}_{90}$ & $t_{10}$ & $\mathbf{t}_{50}$ & $t_{90}$ \\
\hline 4 & - & - & - & $31.2 \mathrm{c}$ & $48.3 \mathrm{~d}$ & $76.0 \mathrm{~d}$ & - & - & - & - & - & - \\
\hline 8 & - & - & - & $18.0 \mathrm{~b}$ & $33.9 c$ & $63.9 \mathrm{c}$ & $24.3 \mathrm{~d}$ & $28.0 \mathrm{~d}$ & $32.4 \mathrm{~d}$ & - & - & - \\
\hline 12 & 12.17 e B & $17.03 \mathrm{~d} \mathrm{~A}$ & $24.38 \mathrm{~d} \mathrm{C}$ & 5.8 a A & $9.7 \mathrm{~b} \mathrm{~A}$ & $16.4 \mathrm{~b} \mathrm{~B}$ & $8.8 \mathrm{c} \mathrm{AB}$ & 10.4 c B & $12.3 \mathrm{c} \mathrm{A}$ & - & - & - \\
\hline 15 & $9.87 \mathrm{~d}$ & $11.34 \mathrm{c}$ & $13.04 \mathrm{c}$ & - & - & - & - & - & - & $3.5 \mathrm{c}$ & $5.7 \mathrm{e}$ & $9.5 \mathrm{~d}$ \\
\hline 16 & - & - & - & $4.1 \mathrm{a}$ & $6.6 \mathrm{ab}$ & $10.8 \mathrm{ab}$ & $5.0 \mathrm{~b}$ & $6.3 \mathrm{~b}$ & $8.1 \mathrm{~b}$ & - & - & - \\
\hline 18 & $3.46 \mathrm{bc}$ & $4.03 \mathrm{~b}$ & $4.70 \mathrm{ab}$ & - & - & - & - & - & - & $3.0 \mathrm{c}$ & $3.6 \mathrm{~d}$ & $4.2 \mathrm{c}$ \\
\hline 20 & - & - & - & $3.6 \mathrm{a}$ & $4.9 \mathrm{a}$ & $6.8 \mathrm{a}$ & $3.6 \mathrm{ab}$ & $4.8 \mathrm{ab}$ & $6.2 \mathrm{ab}$ & - & - & - \\
\hline 21 & $2.87 \mathrm{bc}$ & $3.80 \mathrm{~b}$ & $5.11 \mathrm{ab}$ & - & - & - & - & - & - & $1.7 \mathrm{~b}$ & $2.2 \mathrm{c}$ & $2.8 \mathrm{~b}$ \\
\hline 24 & $1.64 \mathrm{a}-\mathrm{c} B$ & $3.39 \mathrm{~b} \mathrm{~B}$ & 7.06 b C & 3.3 a D & $4.5 \mathrm{a} \mathrm{C}$ & 6.2 a C & 2.3 a C & 3.0 a B & 3.8 a B & $1.0 \mathrm{ab} \mathrm{A}$ & $1.4 \mathrm{~b} \mathrm{~A}$ & $1.8 \mathrm{ab} \mathrm{A}$ \\
\hline 27 & $1.48 \mathrm{ab}$ & $1.87 \mathrm{a}$ & $2.37 \mathrm{a}$ & - & - & - & - & - & - & $0.6 \mathrm{a}$ & $0.9 \mathrm{a}$ & $1.5 \mathrm{a}$ \\
\hline 28 & - & - & - & $1.9 \mathrm{a}$ & $3.4 \mathrm{a}$ & $6.3 \mathrm{a}$ & - & - & - & - & - & - \\
\hline 30 & $0.75 \mathrm{a}$ & $1.89 \mathrm{a}$ & $6.28 \mathrm{~b}$ & - & - & - & - & - & - & - & - & - \\
\hline
\end{tabular}

Different small letters (a-e) within a column indicate statistical difference in each parameter separately for one species by Fisher's Least Significant Difference (LSD) test at $\mathrm{p}<0.05$.

Different big letters (A -D) indicate statistical difference between species in each parameter separately ( $\left.\mathrm{t}_{10}, \mathrm{t}_{50}, \mathrm{t}_{00}\right)$ by Fisher's Least Significant Difference (LSD) test at $\mathrm{p}<0.05$. 
A linear regression line was used to estimate the $\mathrm{T}_{\mathrm{b}}$ of the weed species studied (Figure 1). The highest $\mathrm{T}_{\mathrm{b}}$ value was estimated for $\mathrm{A}$. retroflexus $\left(13.9 \pm 0.36^{\circ} \mathrm{C}\right)$ and the lowest for C. album $\left(3.4 \pm 0.36^{\circ} \mathrm{C}\right)$, while P. capillare and S. pumila presented intermediate values $\left(11.0 \pm 1.99^{\circ} \mathrm{C}\right)$ and $\left(6.6 \pm 0.09^{\circ} \mathrm{C}\right)$, respectively.

63

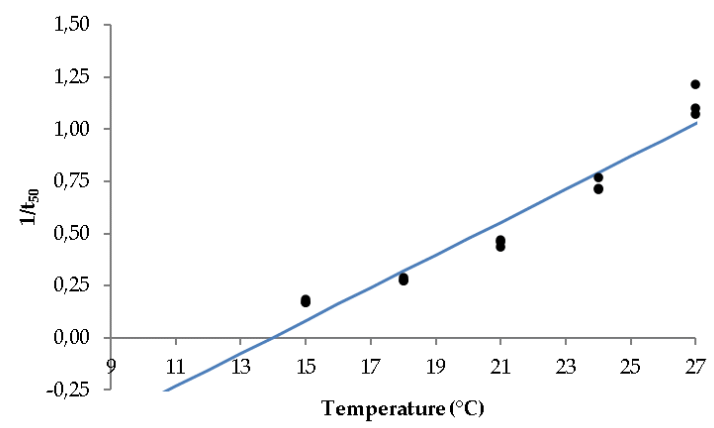

a) Amaranthus retroflexus base temperature $\left(13.9 \pm 0.36^{\circ} \mathrm{C}\right)$

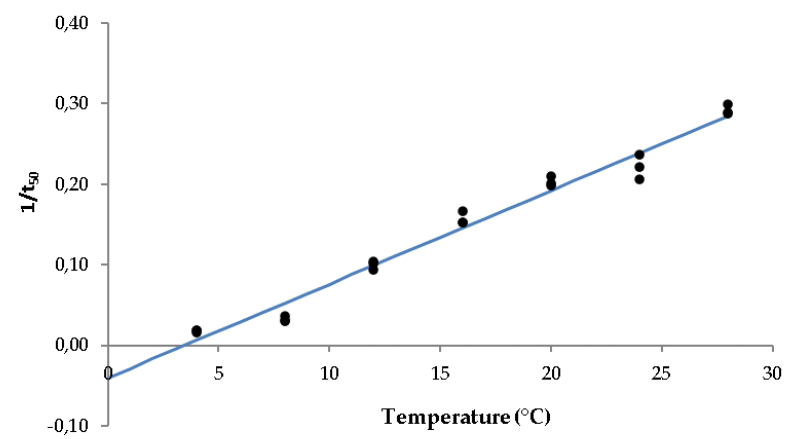

b) Chenopodium album base temperature $\left(3.4 \pm 0.36^{\circ} \mathrm{C}\right)$

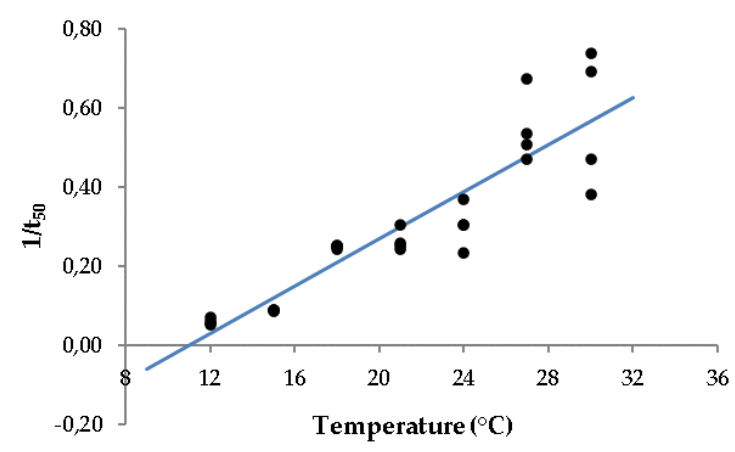

c) Panicum capillare base temperature $\left(11.0 \pm 1.99^{\circ} \mathrm{C}\right)$

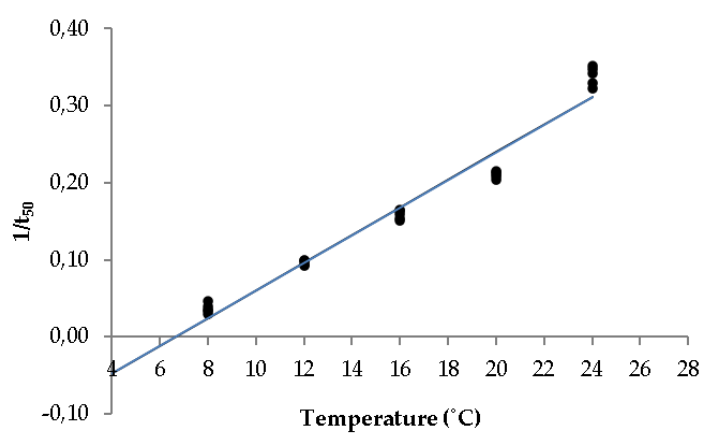

d) Setaria pumila base temperature $\left(6.6 \pm 0.09{ }^{\circ} \mathrm{C}\right)$

Figure 1. Estimated base temperatures. The solid line represents the linear regression line and the points are the calculated germination rate $\left(1 / \mathrm{t}_{50}\right)$. a) Amaranthus retroflexus $\left.\left(\mathrm{T}_{b}=13.9^{\circ} \mathrm{C} ; \mathrm{y}=0.079 \mathrm{x}-1.010 ; \mathrm{r}^{2}=0.96\right) \mathrm{b}\right)$ Chenopodium album $\left.\left(\mathrm{T}_{\mathrm{b}}=3.4^{\circ} \mathrm{C} ; \mathrm{y}=0.012 \mathrm{x}-0.04, \mathrm{r}^{2}=0.98\right) \mathrm{c}\right)$ Panicum capillare $\left(\mathrm{T} \mathrm{b}=11.0^{\circ} \mathrm{C}\right.$; $\left.\left.\mathrm{y}=0.030 \mathrm{x}-0.328 ; \mathrm{r}^{2}=0.82\right) \mathrm{d}\right)$ Setaria pumila $\left(\mathrm{T}_{\mathrm{b}}=6.6^{\circ} \mathrm{C} ; \mathrm{y}=0.018 \mathrm{x}-0.119 ; \mathrm{r}^{2}=\right.$ 
$0.96)$.

3.3. Germination dynamic in response to different water potential and estimation of base water potential for tested weed species

The duration of germination of all weeds varied between 0.4 and $32.3 \mathrm{~d}$, depending on the incubation water potentials and the species tested. In general, the duration of germination increased with the decrease in water potential. The germination was extended in the range depending on the species (Table 4 ).

A. retroflexus showed the highest sensitivity to water stress. After a very low germination at a water potential $<-0.25 \mathrm{MPa}$, it was even not possible to estimate the germination dynamic curve. At a water potential $>-0.25 \mathrm{MPa}$, germination lasted from 0.5 to $3.6 \mathrm{~d}\left(\mathrm{t}_{10}-\mathrm{t}_{90}\right)$ and at $-0.25 \mathrm{MPa}$, germination lasted $18.6 \mathrm{~d}\left(\mathrm{t}_{90}\right)$. Other species required longer time to reach initial germination phase $\left(\mathrm{t}_{10}\right)$ at a water potential $<-0.25 \mathrm{MPa}$, but then they were able to maintain similar germination dynamics until -0.38 and $-0.50 \mathrm{MPa}$ for S. pumila, C. album and P. capillare, respectively C. album was the only species with the ability to germinate at all investigated water potentials. 
Table 4. Germination dynamic at different water potential (MPa) at $22^{\circ} \mathrm{C}$.

\begin{tabular}{|c|c|c|c|c|c|c|c|c|c|c|c|c|}
\hline \multirow{2}{*}{$\mathrm{MPa}$} & \multicolumn{3}{|c|}{ P. capillare } & \multicolumn{3}{|c|}{ C. album } & \multicolumn{3}{|c|}{ S. pumila } & \multicolumn{3}{|c|}{ A. retroflexus } \\
\hline & $t_{10}$ & $\mathbf{t}_{50}$ & $t_{90}$ & $\mathbf{t}_{10}$ & $\mathbf{t}_{50}$ & $t_{90}$ & $\mathbf{t}_{10}$ & $\mathbf{t}_{50}$ & t90 & $\mathbf{t}_{10}$ & $t_{50}$ & $t_{90}$ \\
\hline 0.00 & $4.6 \mathrm{bc}$ & $5.0 \mathrm{a}$ & $5.5 \mathrm{a}$ & $2.1 \mathrm{a}$ & $3.4 \mathrm{a}$ & $5.7 \mathrm{a}$ & $2.5 \mathrm{a}$ & $3.5 \mathrm{a}$ & $4.8 \mathrm{a}$ & $1.4 \mathrm{a}$ & $1.6 \mathrm{a}$ & $1.9 \mathrm{a}$ \\
\hline-0.05 & $4.7 \mathrm{bc}$ & $5.2 \mathrm{a}$ & $5.7 \mathrm{a}$ & $2.2 \mathrm{a}$ & $3.4 \mathrm{a}$ & $5.5 \mathrm{a}$ & $3.1 \mathrm{a}$ & $3.9 \mathrm{a}$ & $5.0 \mathrm{a}$ & $1.2 \mathrm{~b}$ & $1.6 \mathrm{a}$ & $2.3 \mathrm{a}$ \\
\hline-0.10 & $4.6 \mathrm{bc}$ & $5.2 \mathrm{a}$ & $5.8 \mathrm{a}$ & $2.2 \mathrm{a}$ & $3.5 \mathrm{a}$ & $5.5 \mathrm{a}$ & $3.4 \mathrm{a}$ & $4.2 \mathrm{a}$ & $5.2 \mathrm{a}$ & $0.5 \mathrm{bc}$ & $1.3 \mathrm{a}$ & $3.6 \mathrm{a}$ \\
\hline-0.25 & $4.0 \mathrm{ab}$ & $6.2 \mathrm{ab}$ & $10.0 \mathrm{ab}$ & $2.3 \mathrm{a}$ & $3.7 \mathrm{a}$ & $5.8 \mathrm{a}$ & $3.3 \mathrm{a}$ & $5.3 \mathrm{a}$ & $7.4 \mathrm{a}$ & $1.9 \mathrm{c}$ & $5.9 \mathrm{~b}$ & $18.6 \mathrm{~b}$ \\
\hline-0.38 & $3.5 \mathrm{a}$ & $7.5 \mathrm{~b}$ & $17.9 \mathrm{~b}$ & $2.0 \mathrm{a}$ & $3.7 \mathrm{a}$ & $6.8 \mathrm{a}$ & $3.9 \mathrm{a}$ & $6.8 \mathrm{a}$ & $12.1 \mathrm{~b}$ & - & - & - \\
\hline-0.50 & $4.9 \mathrm{c}$ & $7.5 \mathrm{~b}$ & $12.8 \mathrm{ab}$ & $2.4 \mathrm{a}$ & $4.7 \mathrm{~b}$ & $9.1 \mathrm{a}$ & $10.1 \mathrm{~b}$ & $18.0 \mathrm{~b}$ & $32.3 \mathrm{c}$ & - & - & - \\
\hline-0.80 & - & - & - & $4.5 \mathrm{c}$ & $9.6 \mathrm{~d}$ & $21.4 \mathrm{~b}$ & - & - & - & - & - & - \\
\hline-1.00 & - & - & - & $3.7 \mathrm{~b}$ & $8.2 \mathrm{c}$ & $18.8 \mathrm{~b}$ & - & - & - & - & - & - \\
\hline
\end{tabular}

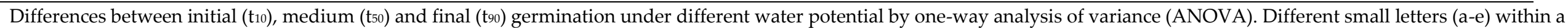
column indicate statistical difference by Fisher's Least Significant Difference (LSD) test at $\mathrm{p}<0.05$. 
Consequently, $\Psi_{\mathrm{b}}$ was estimated with the germination dynamics shown in Table 3 . and presented in Figure 2. The lowest value was estimated for C. album $(-1.38 \pm 0.14$ $\mathrm{MPa})$ and the highest for A. retroflexus $(-0.36 \pm 0.03 \mathrm{MPa})$ while S. pumila $(-0.71 \pm 0.07$ $\mathrm{MPa})$ and $\mathrm{P}$. capillare $(-0.86 \pm 0.07 \mathrm{MPa})$ had an intermediate value.

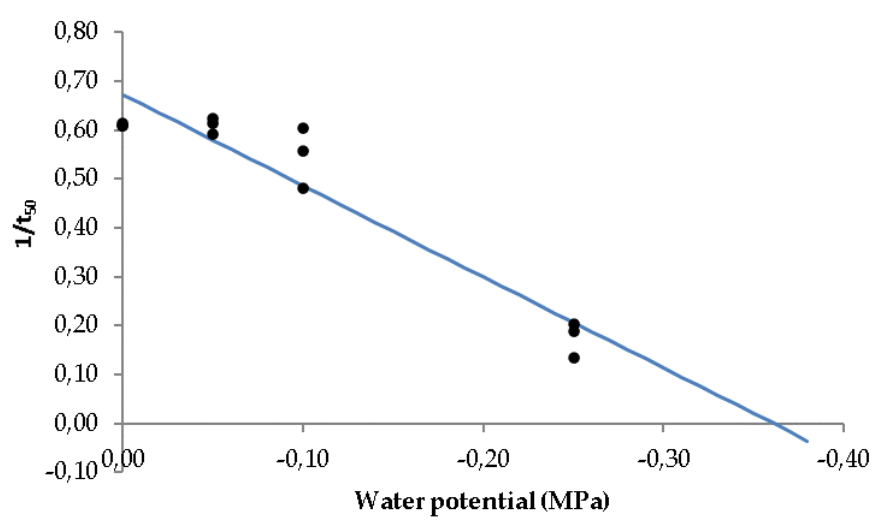

a) Amaranthus retroflexus $(-0.36 \pm 0.03 \mathrm{MPa})$

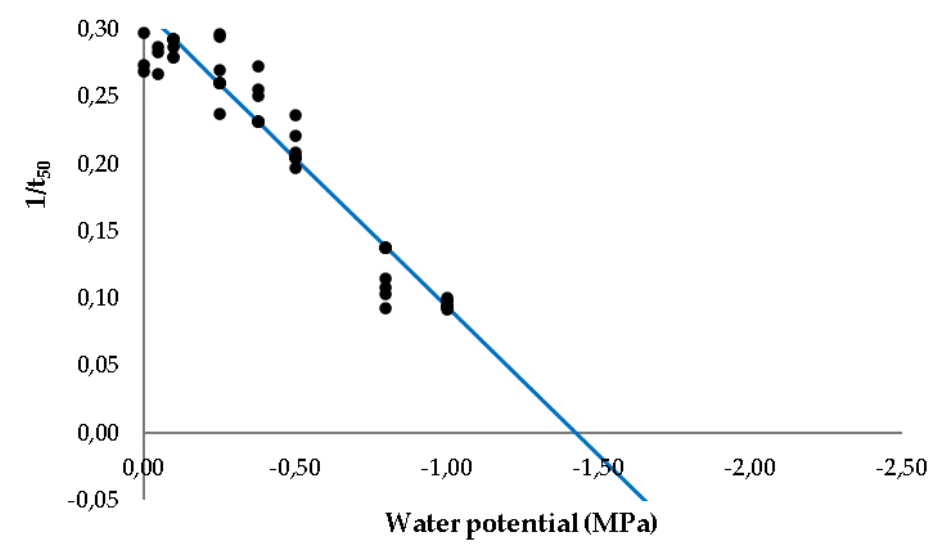

b) Chenopodium album $(-1.38 \pm 0.14 \mathrm{MPa})$

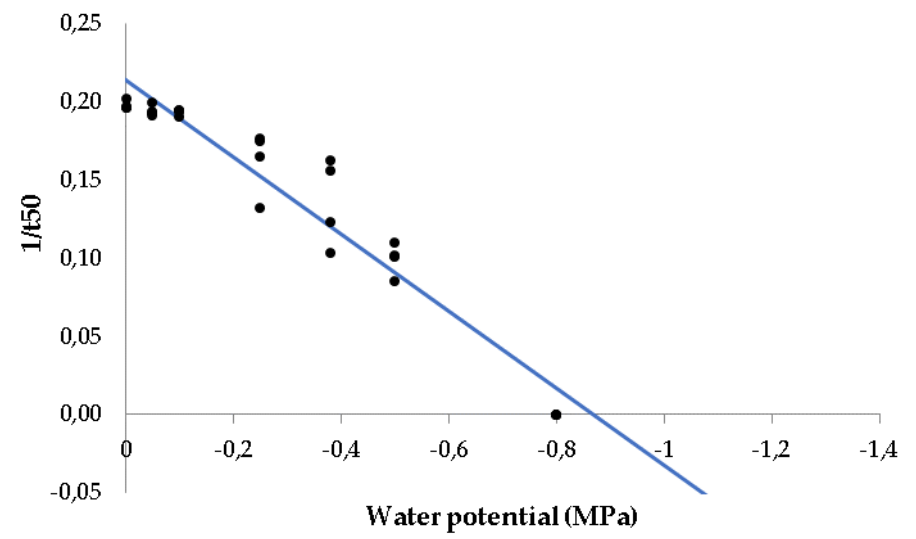

c) Panicum capillare $(-0.86 \pm 0.07 \mathrm{MPa})$ 


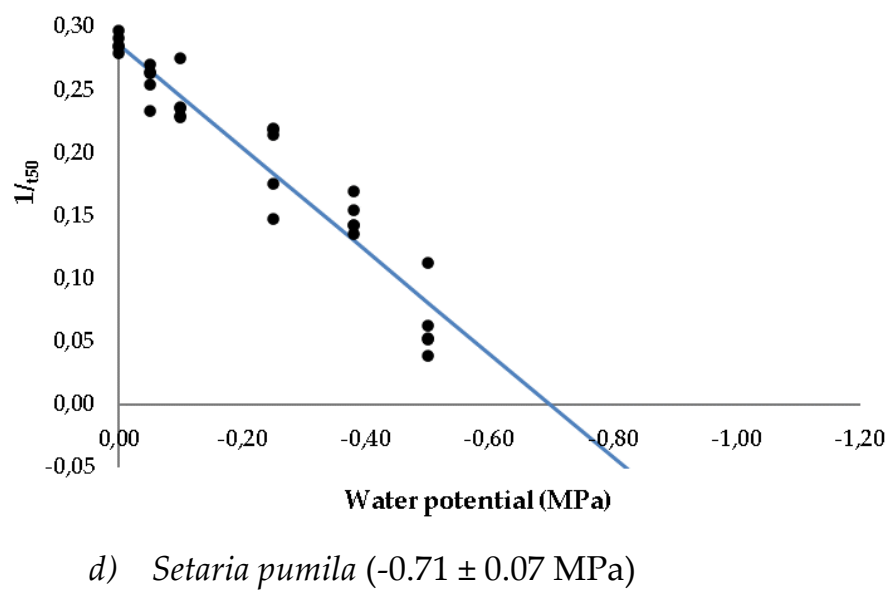

Figure 2. Estimated base water potentials $\left(\Psi_{\mathrm{b}}\right)$. The solid line represents the linear regression line and the points are the calculated germination rate $\left(1 / \mathrm{t}_{50}\right)$ : a) Amaranthus retroflexus $\left.\left(\Psi_{b}=-0.36 \mathrm{MPa} ; \mathrm{y}=0.672 \mathrm{x}+1.862 ; \mathrm{r}^{2}=0.91\right) \mathrm{b}\right)$, Chenopodium album $\left.\left(\Psi_{\mathrm{b}}=-1.42 \mathrm{MPa} ; \mathrm{y}=0.221 \mathrm{x}+0.315 ; \mathrm{r}^{2}=0.87\right) \mathrm{c}\right)$, Panicum capillare $\left(\Psi_{\mathrm{b}}=-0.86\right.$ $\left.\mathrm{MPa} ; \mathrm{y}=0.2466 \mathrm{x}+0.2138 ; \mathrm{r}^{2}=0.94\right)$ and $\left.\mathrm{d}\right)$ Setaria pumila $\left(\Psi_{\mathrm{b}}=-0.70 \mathrm{MPa} ; \mathrm{y}=0.409 \mathrm{x}\right.$ $\left.+0.286 ; \mathrm{r}^{2}=0.92\right)$.

It is important to underline that for P. capillare it was not possible to use the logistic regression model to identify the $t_{50}$ at $-0.80 \mathrm{MPa}$, due to the low germination (Table 2). However, a value of $1 / t_{50}$ close to zero was used at $-0.80 \mathrm{MPa}$ to estimate the base water potential. It was necessary to avoid underestimation of the base parameter.

\subsection{Comparison of biological parameters of Italian and Croatian populations}

According to the criterion of overlap of the $95 \%$ confidence interval [1] between Italian and Croatian populations, two out of three species tested have similar values in an estimated parameter (Table 5). For P. capillare it was not possible to make a comparison because the biological parameters of the Italian population of this species have not yet been estimated.

The Croatian population of A. retroflexus had a $1.6^{\circ} \mathrm{C}$ higher base temperature compared to Italian populations, and the overlap was not found even if the extreme of the two confidence intervals were close. So, these two values of $\mathrm{T}_{\mathrm{b}}$ can be considered as statistically different. In the Croatian population of C. album $\mathrm{T}_{\mathrm{b}}$ was $0.8^{\circ} \mathrm{C}$ higher than in the Italian population, but the confidence intervals overlapped. These two values are therefore not statistically different. In contrast, $\mathrm{T} b$ value estimated for the Croatian population of S. pumila is $3.81^{\circ} \mathrm{C}$ lower compared to the Italian population and it was found that they differed significantly.

Base water potential of A. retroflexus was $0.05 \mathrm{MPa}$ higher for the Croatian population compared to Italy but no significant difference was found. Lower base water potential was determined for the Croatian population of C. album, and higher for S. pumila, anyhow significant differences from the Italian population were found in both cases. Taken together, similar values between Italian and Croatian populations were found only for $\mathrm{C}$. album regarding $\mathrm{T}_{\mathrm{b}}$ and for $\mathrm{A}$. retroflexus regarding $\Psi_{\mathrm{b}}$. 
Table 5. Base temperature $\left(\mathrm{T}_{\mathrm{b}}\right)$ and base water potential $\left(\Psi_{\mathrm{b}}\right)$ of weed species for Italian and Croatian population, confidence interval $(95 \% \mathrm{CI})$ and coefficient of determination $\left(\mathrm{r}^{2}\right)$. Italian biological parameters for three weed species (A. retroflexus, C. album, S. pumila) were estimated by Masin et al. [1].

\begin{tabular}{|c|c|c|c|c|c|c|c|c|c|c|c|c|}
\hline Species & \multicolumn{3}{|c|}{ Italy } & \multicolumn{3}{|c|}{ Croatia } & \multicolumn{3}{|c|}{ Italy } & \multicolumn{3}{|c|}{ Croatia } \\
\hline C. album & 2.6 & 0.77 & 0.84 & 3.4 & 0.36 & 0.98 & -0.96 & 0.10 & 0.84 & -1.42 & 0,14 & 0.87 \\
\hline P. capillare & - & - & - & 11.0 & 1.99 & 0,82 & - & - & - & -0.86 & 0.07 & 0.94 \\
\hline
\end{tabular}




\section{Discussion}

In the present study biological parameters for germination $\left(\mathrm{T}_{\mathrm{b}}\right.$ and $\left.\Psi_{\mathrm{b}}\right)$ of four summer weed species collected in Croatia were estimated. Germination tests at different temperatures showed a species-specific preference for higher or lower temperatures. Species are ranged from less to more thermophilic as follow: C. album $>$ S. pumila $>P$. capillare $>A$. retroflexus. This is consistent with previous studies in which A. retroflexus also germinated best at temperatures $>25^{\circ} \mathrm{C}$ [24] and S. pumila at temperatures of 24.5 to $34.9^{\circ} \mathrm{C}$ [25]. In the present study $P$. capillare had the highest germination at temperatures of $18-24^{\circ} \mathrm{C}$ again consistent with previous study where $P$. dichotomiflorum achieved the highest germination capacity at temperatures of $25^{\circ} \mathrm{C}$ [26-29] or P. miliaceaeum at temperatures between 18 and $25^{\circ} \mathrm{C}$ [30,31]. Optimal temperature for germination of $C$. album has been reported between 15 and $25^{\circ} \mathrm{C}$ [32], which is again in line with the germination data of the present study (Table 1).

If we related the temperature preferences that define germination to the time of emergence in the field, as suggested in a previous study [2], the species from the present study could be divided into three categories: early (C. album), middle (S. pumila and $P$. capillare) and late emerging species (A. retroflexus). The germination dynamic data shown in this study (Table 3 ) also reflected the species-specific sensitivity to different temperatures. In particular, A. retroflexus had the shortest germination at all temperatures investigated. For example, the mean germination of this species stopped completely after 5.7 days, which is slightly faster compared to other species in the study (Table 3). Germination stopped completely at $12^{\circ} \mathrm{C}$ confirming its thermophilic behavior [2]. $\mathrm{Tb}$ values for $A$. retroflexus is estimated to be $13.9^{\circ} \mathrm{C}$, which is the highest $\mathrm{Tb}$ among the species tested in the present study. This is the reason why later emergence is observed for A. retroflexus in maize fields compared to other weeds studied [33]. This $\mathrm{T}_{\mathrm{b}}$ is slightly higher than the values around $12^{\circ} \mathrm{C}$ reported for Italian and Iranian populations $[1,11]$ and even lower values, i.e. 10.5 and $8.9^{\circ} \mathrm{C}$, have been reported for other populations from Germany and France respectively $[19,34]$. In contrast, our study estimated that $\mathrm{T}_{\mathrm{b}}$ for C. album is $3.4^{\circ} \mathrm{C}$ making it the species with the lowest temperature requirement confirming its early germination behavior [2]. This value is similar to the $\mathrm{T}_{\mathrm{b}}$ reported for Italian and Dutch populations $[1,35]$ while a significantly higher value was described for a French population [19]. The value of $\mathrm{Tb}\left(6.6^{\circ} \mathrm{C}\right)$ estimated for the Croatian population of S. pumila is lower than the range of values $\left(8.6-10.4{ }^{\circ} \mathrm{C}\right)$ reported in previous studies on populations from Italy, French and California $[1,19,30]$. In our study we also estimated $\mathrm{T}_{\mathrm{b}}$ for P. capillare, and as far as we know, this is the first report globally on base temperature for this weed species. We found that $11^{\circ} \mathrm{C}$ is the base temperature for P. capillare. Our results are consistent with the study where the minimum temperature for germination of $P$. miliaceaum was estimated to be also $11^{\circ} \mathrm{C}$ [31].

Since temperature is not the only factor triggering germination in the present study, we also observed the germination capacity of the same weed species under different water potentials. Depending on water requirements, the species in this study are ranged from less to more tolerant as follow: A. retroflexus $\left(\Psi_{\mathrm{b}}-0.36 \mathrm{MPa}\right)<$ S. pumila $\left(\Psi_{\mathrm{b}}-0.71\right.$ $\mathrm{MPa})<$ P. capillare $\left(\Psi_{\mathrm{b}}-0.86 \mathrm{MPa}\right)<$ C. album $\left(\Psi_{\mathrm{b}}-1.38 \mathrm{MPa}\right)$ (Figure 2$)$. In addition to the study performed to calibrate AlertInf model [1], only a single study conducted in France has already determined $\Psi_{\mathrm{b}}$ for these species [19]. The value of $\Psi_{\mathrm{b}}$ estimated for the Croatian population of $A$. retroflexus is similar to the $\Psi_{\mathrm{b}}$ used in AlertInf for a population from Northern Italy, while lower values were reported for other populations from Central Italy (-0.62 MPa) or France (-0.95 MPa) [1,19]. Regarding $\Psi_{b}$ for $S$. pumila, an almost identical value was described for a French population (-0.75 vs $-0.71 \mathrm{MPa})$ while a lower value was determined for the Italian population included in AlertInf $[1,19]$. Finally, the Croatian population of $C$. album had a lower $\Psi_{\mathrm{b}}$ in comparison with the values previously reported for both Italian (-0.96 and $-1.04 \mathrm{MPa})$ and French (-0.80 MPa) populations [1,19]. For the species $P$. capillare as far as we know there are no data of $\Psi_{\mathrm{b}}$ in the literature. Germination behavior of the investigated species at different temperature and water po- 
tential regimes shows that the species with a better tolerance to lower temperatures also had a better tolerance to lower-water potential.

The main objective of the present study was to compare the estimated values of the Croatian population with Italian populations of C. album, S. pumila and A. retroflexus included in the hydrothermal model AlertInf. We wanted to examine if the $\mathrm{T}_{\mathrm{b}}$ and $\Psi_{\mathrm{b}}$ values estimated in this study would be comparable with those in Alertinf [4] as a first step of transferring weed predictive model AlertInf in Croatian maize fields. Two out of three Croatian species had a parameter overlapping with the Italian population: C. album had similar $\mathrm{T}_{\mathrm{b}}$, but different $\Psi_{\mathrm{b}}$, A. retroflexus different $\mathrm{T}_{\mathrm{b}}$ but similar $\Psi_{\mathrm{b}}$. and S. pumila differed in both germination parameters (Table 5).

Present study therefore showed that similar germination of Croatian and Italian population may only be expected for C. album since the $\mathrm{T}_{\mathrm{b}}$ value was similar. However, this is valid only in conditions were soil water is not limited since $\Psi_{\mathrm{b}}$ differed significantly between two populations. Next step therefore will be to evaluate the weed emergence patterns of $C$. album in irrigated maize fields in Croatia and then try to calibrate the AlerInf equation parameters. Prediction of $A$. retroflexus and S. pumila by AltertInf model with its original parameters is unfortunately impossible, even in irrigated maize crops, since the $\mathrm{T}_{\mathrm{b}}$ values differ statistically with those Italian presents in the hydrothermal model. This variability in germination parameters has also been documented in previous studies and usually explained as adaptation process of weed species to local climate conditions $[13,36]$. The annual air temperature in Zagreb is on average lower than those in Padova (Table 1). Moreover, compering the temperatures in spring (March-June) and summer (July-October) in Zagreb $\left(6.4-19.4^{\circ} \mathrm{C} ; 21.1-11.0^{\circ} \mathrm{C}\right)$ and Padova $\left(9.0-22.0^{\circ} \mathrm{C}\right.$; $23.1-14.0^{\circ} \mathrm{C}$ ) during a thirty-year period it is evident that Zagreb has lower air temperatures. Therefore, we expected that populations in Zagreb and the surrounding area would have lower $\mathrm{T}_{\mathrm{b}}$ values compared to those in Padova as suggested earlier [1, 12]. This was accomplished for S. pumila and C. album, however this phenomenon was not found for A. retroflexus, where $\mathrm{T}_{\mathrm{b}}$ is higher for the Croatian (colder climate) than for the Italian population (warmer climate). Unfortunately, the complexity of weed seed biology, especially in the period of seed ripening, can influence the germination behavior of seeds. The involvement of various factors that determine the characteristics of the seed (position on the mother plant, micro-environmental conditions, availability of nutrients, etc.) can cause the difference in dormancy and germination requirements [37,38]. An attempt to implement the model in another agro-ecological area was also made by these Bürger and Colbach [15] for the FlorSys model. The difference in base temperature for different species was also species-specific and unable to find the pattern connected to climate conditions. They have found 4.3 lower $\mathrm{T}_{\mathrm{b}}$ for $\mathrm{C}$. album and $4.0^{\circ} \mathrm{C}$ higher $\mathrm{T}_{\mathrm{b}}$ E. crus-galli in Germany compared to France.

\section{Conclusions}

C. album, A. retroflexus, S. pumila and P. capillare are highly distributed weed species globally [39] and in Croatian maize fields [40]. Present study offers the ability to implement the predictive emergence model AlertInf only for C. album in non-irrigated field. However, the results are valuable since it provides estimated biological parameters of four species, which have never been estimated before in Croatia. This is the first and obligatory step towards developing/transferring a model to predict their emergence.

However, further field experiment is necessary and should be performed in two directions depending on the weed species. First, for C. album or A. therophrasti since their estimated $\mathrm{T}_{\mathrm{b}}$ are overlapping with Italian populations [16], the AlertInf has to be further validated by comparing the emergence of species in maize fields with those predicted with AlertInf. Secondly, the model should be adapted for species S. pumila and A. retroflexus since biological parameters differed significantly. And the third, AlertInf should be upgraded for $P$. capillare whose biological parameters have now been estimated for the first time. 


\begin{abstract}
Author Contributions: Conceptualization, V.Š., M.Š. and R.M.; methodology, R.M and D.L..; software, R.M.; validation, all authors.; formal analysis R.M. and V.Š.; investigation, V.Š and E. B.; resources, R.M., D. L., M.Š.; data curation, V.Š. and E.B..; writing-original draft preparation, V.Šs. and M.Š..; writing - review and editing, all authors; visualization, V.Š.; supervision, M.Š. and R.M.; project administration, M.Š..; funding acquisition, R.M. and M.Š. All authors have read and agreed to the published version of the manuscript.", please turn to the CRediT taxonomy for the term explanation. Authorship must be limited to those who have contributed substantially to the work reported.
\end{abstract}

Funding: This research received no external funding.

Conflicts of Interest: The authors declare no conflict of interest.

\title{
References
}

1. Masin R.; Loddo D.; Benvenuti S.; Zuin M.C.; Macchia M; Zanin G. Temperature and water potential as parameters for modeling weed emergence in central-northern Italy. Weed Sci.2010, 58, 216-222.

2. Werle R.; Sandell L.D.; Buhler D.D.;Hartzler R.G.; Lindquist J.L.Predicting emergence of 23 summer annual weed species. Weed Sci.2014, 62, 267-279.

3. Forcella, F.; R. L. Benech Arnold; R. Sanchez; C. M. Ghersa. Modelling seedling emergence. Field Crops Res. 2000 67, $123-139$

4. Masin R.; Loddo D.; Benvenuti S.; Otto S.; Zanin G. Modeling weed emergence in Italian maize fields. Weed Sci.2012, 60, 254259

5. Dorado J.; Sousa E.; Cahla I.M.; González-Andújar J.M.; Fernández-Quintanilla C. Predicting weed emergence in maize crops under two contrasting climatic conditions. Weed Res. 2009, 49, 251-260.

6. Masin R.; Loddo D.; Gasparini V.; Otto S.; Zanin G. Evaluation of weed emergence model AlertInf for maize in soybean. Weed Sci.2014, 62, 360-369.

7. Royo-Esnal A.; García A.L.; Torra J.; Forcella F.; Recasens J. Describing Polygonum aviculare emergence in different tillage systems. Weed Res. 2015, 55, 387-395.

8. Izquierdo J.; Bastida F.; Lezaún J.M.; Sánchez del Arco M.J.; González-Andújar J.L. Development and evaluation of a model for predicting Lolium rigidum emergence in winter cereal crops in the Mediterranean area. Weed Res. 2013, 53, $269-278$.

9. Bradford, K. J. Applications of hydrothermal time to quantifying and modeling seed germination and dormancy. Weed Sci. 2002, 50:248-260.

10. Leguizamon, E. S.; Fernandez-Quintanilla C.; Barroso J.; Gonzalez- Andujiar J. L. Using thermal and hydrothermal time to model seedling emergence of Avena sterilis ssp. ludoviciana in Spain. Weed Res. 2005, 45:149-156.

11. Loddo D.; Ghaderi-Far F.; Rastegar Z.; Masin R. Base temperatures for germination of selected weed species in Iran. Plant Protect. Sci. 2018, 54: 60-66.

12. CBS - Croatian Bureau of Statistics. Available online: https://www.dzs.hr/default e.htm (accessed on 15 November 2020).

13. Loddo, D.; Sousa E.; Masin R.; Calha, I.; Zanin, G.; Fernández-Quintanilla, C.; Dorado, J. Estimation and Comparison of Base Temperatures for Germination of European Populations of Velvetleaf (Abutilon theophrasti) and Jimsonweed (Datura stramonium). Weed Sci.2013, 61, 3, 443-451.

14. Leiblein-Wild, M.C.; Kaviani, R.; Tackenberg, O. Germination and seedling frost tolerance differ between the native and invasive range in common ragweed. Oecologia 2014; 174, 739-750.

15. Bürger, J.; Colbach, N. Germination base temperature and relative growth rate of 13 weed species - comparing populations from two geographical origins, 28th German Conference on Weed Biology and Weed Control, Julius-Kuhn-Archiv 2018, 458: $419-426$

16. Šoštarčić, V.; Šćepanović, M.; Masin, R.; Magosso, D.; Zanin, G. Estimation of biological parameters for germination of Abutilon theophrasti Med. Period. Biol 2018, 120, 2 -3, $81-89$.

17. Kottek M.; Grieser J.; Beck C.; Rudolf B.; Rubel F. World map of the Koppen-Geiger climate classificationupdated. Meteorol. Z. 2006, 15, 259-263.

18. Steinmaus, S. J., T. S. Prather, and J. S. Holt. Estimation of base temperatures for nine weed species. J. Exp. Bot. 2005, 1, 275-286.

19. Guillemin, J.P.; Gardarin, A.; Granger, S.; Reibel, C.; Munier-Jolain, N.; Colbach, N. Assessing potential germination period of weeds with base temperatures and base water potentials. Weed Res. 2013, 53, 76-87.

20. Masin R.; Zuin M. C.; Archer, D. W.; Zanin, G. WeedTurf: a predictive model to aid control of annual summer weeds in turf. Weed Sci.2005, 53, 193-201.

21. Michel, B.E.; Kaufmann, M.R. The Osmotic Potential of Polyethylene Glycol 6000. Plant Physiol. 1973, 51, 914-916.

22. Onofri, A. Bioassay97: A new Excel VBA macro to perform statistical analyses on herbicide dose-response data. Ital. J. Agrometeorol. 2001. 3, 40-45

23. Efron, B.. Bootstrap methods: another look at the jackknife. Ann. Statist. 1979, 7, 1-26.

24. Steckel E. L.; Sprague, C. L.; Stoller E. W.; Wax. L. M. Temperature Effects on Germination of Nine Amaranthus Species. Weed Sci.2004, 52, 2, 217-221.

25. Mollaee, M.; Darbandi, E.I.; Aval, M.B., Chauhan, B.S. Germination response of three Setaria species (S. viridis, S. verticillata, and S. glauca) to water potential and temperature using non-linear regression and hydrothermal time models. Acta Physiol. Plant $2020,42,149$. 
26. Rivera, C.M.; Peters, R.A. A preliminary report on formation of seed and germination of fall panicum (Panicum dichotomiflorum Michx.) and witchgrass (P. capillare L.). Proc. Newcc 1971, 25, 30.

27. Vengris, J.; Damon, R.A. Field growth of fall panicum and witchgrass. Weed Sci. 1976 24, 205-208.

28. Baskin, J. M., Baskin, C. C. Seasonal changes in the germination responses of buried witchgrass (Panicum capillare) seeds. Weed Sci. 1986, 34, 22-24

29. Smith, A.A. The effects of seed mass and emergence order on growth and reproduction of fall panicum (Panicum dichotomiflorum Michx.). M.S. Thesis. The Ohio State University. Columbus. OH, 1986.

30. Kalinová, J.; Moudrý, J. Frost resistance evaluation of the common millet (Panicum miliaceum L.) varieties. Agricultura 2005, 3:10-12.

31. James, T.K.; Rahman, A.; Mcgill, C.R.; Trivedi, P.D. Biology and survival of broom corn millet (Panicum miliaceum) seed. N. Z. Plant Prot. 2011, 64, 142-148.

32. Altenhofen, L. M. The effects of light, temperature, after-ripening, nitrate and water on Chenopodium album seed germination. Graduate Theses and Dissertations 2009

33. Myers M.W.; Curran W.S.; VanGessel M.J.; Calvin D.D.; Mortensen D.A.; Majek B.A.; Karsten H.D.; Roth G.W. Predicting weed emergence for eight annual species in the northeastern United States. Weed Sci.2004, 52, 6 , 913-919.

34. Bürger J; Malyshev, A.V.; Colbach, N. Populations of arable weed species show intraspecific variability in germination base temperature but not in early growth rate. PLoS ONE 2020 15(10): e0240538. https://doi.org/10.1371/journal.pone.0240538

35. Vleeshouwers, L. M. and M. J. Kropff.. Modelling field emergence patterns in arable weeds. New Phytol. 2000, $148,445-457$.

36. Loddo, D., Bozic, D., Calha, I.M., Dorado, J., Izquierdo, J., Šćepanović, M., Barić, K., Carlesi, S., Leskovsek, R., Peterson, D., Vasileiadis, V.P., Veres, A., Vrbničanin, S., Masin, R. Variability in seedling emergence for European and North American populations of Abutilon theophrasti.Weed Res. 2019, 59 (1). 15-27. DOI: 10.1111/wre.12343

37. Fenner M. The effects of the parent environment on seed germinability. Seed Sci. Res. 1991, 1, 75-84.

38. Baskin, C. C.; Baskin, J. M. Seed ecology, biogeography, and evolution of dormancy and germination. School of Biological Sciences, University of Kentucky, Academic press 2001, $181-219$

39. Holm, L.; Doll, J.; Holm, E.; Pancho, J.; Herberger, J. World weeds: natural histories and distribution. Wiley 1997, New York, USA.

40. Šarić T., Ostojić Z., Stefanović L., Deneva Milanova S., Kazinczi G., Tyšer L. The changes of the composition of weed flora in southeastern and central europe as affected by cropping practices. Herbologia 2011, 12: 8-12. 